\title{
SOAS Library: Chinese art and archaeology collection
}

\author{
Fiyeon Wood
}

\begin{abstract}
Chinese art has always been well-represented within SOAS Library. This article provides an overview of the Chinese art and archaeology collection, highlighting materials that make it unique, from rare books to literati paintings and woodblock prints. As the Library approaches its centenary, some of the issues that have influenced its past, such as limitations of space, are still informing its future. With increasing attention paid to modern and contemporary Chinese art, efforts have been made to build the collection to reflect this emphasis. As it has throughout SOAS's history, the Library and the Chinese art and archeology collection continue to evolve to reflect new research interests, academic courses and the needs of its users.
\end{abstract}

\section{SOAS Library}

The School of Oriental and African Studies (SOAS) library is regarded as one of the most important academic libraries relating to Asia, Africa and the Middle East. Its history goes back almost 100 years. With a primary aim to respond to growing interests in the East and to train officials in culture and language, the School of Oriental Studies (SOS) in the University of London was established in 1916, with the library exchanging its Western language materials for books and journals about Oriental subjects held by the libraries of University College London, King's College London and the University General Library. The School changed its name to the School of Oriental and African Studies (SOAS) in 1938.

SOAS Library expanded rapidly from its initial 9,000 volumes as a consequence of the recommendations of two reports. ${ }^{1}$ The Scarbrough Report $(1945)^{2}$ was a milestone for the development of the School, highlighting the need to build strong departments, primarily in the study of languages and related cultures. As the School expanded, the Library collection grew quickly and soon exceeded the building's capacity of 100,000 volumes. By 1948, the Library's collections were scattered across various locations $^{3}$ and an urgent need for a new building was recognised. In 1961, the Hayter report recommended that financial support should be provided for the
SOAS Library to operate fully as a national library ${ }^{4}$ and the new Library building was formally opened on $5^{\text {th }}$ October 1973 with space for some one million volumes. For the first time, all the collections were brought together to one location in Bloomsbury.

The Library's current size is estimated at over 1.3 million volumes. Although mobile shelving initially alleviated space limitations, the Library Transformation Project was launched to accommodate growth in line with the School's ten year vision and strategy to address changes in study and research styles. ${ }^{5}$ Phase 1 , to refurbish the ground and below-ground floors, was completed in 2011, with the guiding principles of open shelving and ease of accessibility of the collections for the users.

Furthermore, the Library is also participating in the Bloomsbury Library Management System consortium which consists of five colleges (Birkbeck, Institute Of Education, London School of Hygiene \& Tropical Medicine, Royal Veterinary College and SOAS) and Senate House Library, to build a new Library Management System enabling sharing of resources between each library. Technology is also being utilised to address changes in teaching: slides, once a vital resource for images, are being replaced by electronic visual image databases; films \& documentaries, although still held in video and DVD formats, are being superseded by databases offering streaming; the SOAS library e-book collection is being developed. 
With SOAS Library designated as one of the five national research libraries in the U.K., it holds rare, historical collections that have international importance, including pre-1960 materials published in Asia and Africa, which are often unavailable even in the countries of origin. ${ }^{6}$ The Library's current mission statement is 'to provide high quality information services and resources to reflect and support the School's standing as a leading international Centre of excellence for the research, learning and teaching of Asia, the Middle East and Africa'. ${ }^{7}$ It serves scholars within and outside the School as well as the general public. On average about 8000 external users access the Library every year.

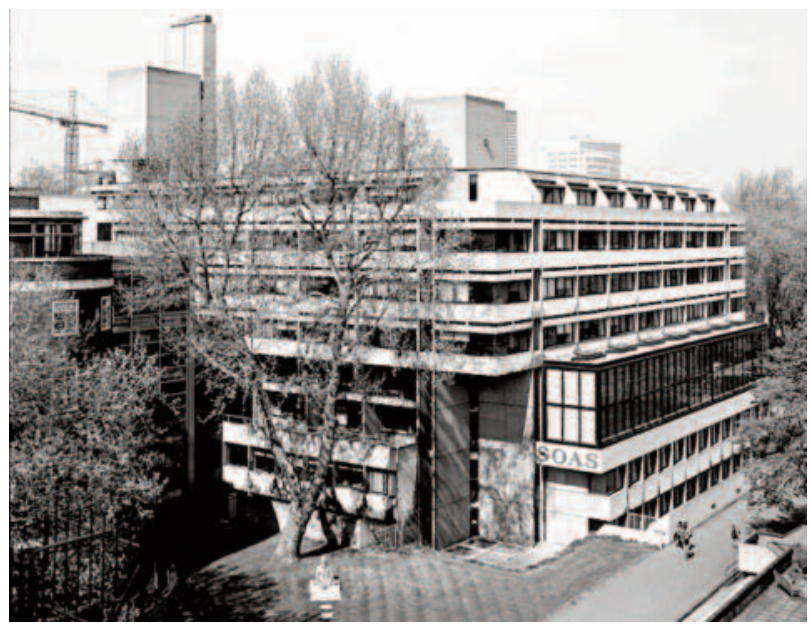

SOAS Library in Bloomsbury. @SOAS Imagebank

\section{Art \& Archaeology Collection}

Although the School began as a language teaching and research institute, books on art and archaeology have always been well-represented in the Library's collection. The history of art and archaeology were popular subjects for the School's public lectures in the 1920s, and of the twenty-six established posts in the Far East department, roughly half were allocated to related studies such as philosophy, religion, the history of art and archaeology. ${ }^{8}$

The two main benefactors behind the establishment of Art \& Archaeology Collection in the SOAS Library were George Eumorfopoulos (18631939) and Sir Percival David (1892-1964). Both were internationally well known art collectors, scholars in Chinese ceramics as well as prominent businessmen. George Eumorfopoulos, with significant collections in Tang and Song dynasty ware, played a significant role in setting up the Courtauld Institute in 1932 . He donated more than 1,500 books and pamphlets to the Courtauld library, including about 200 Chinese and
Japanese language publications, journals and the selection of magnificent art books. ${ }^{9}$ Sir Percival David, with collections of Chinese ceramics, paintings and rare books, was also a renowned scholar of Chinese art and contributed to Chinese art education in Britain. David donated $\$ 500$ to the School of Oriental Studies to found the first 'Chinese Art and Archaeology' university degree course in 1930 and later bequeathed his collection to the University of London, SOAS's governing institution. ${ }^{10}$

With the centre for teaching of Chinese Art moving from the Courtauld Institute to SOAS, primarily through the establishment of Sir Percival David Foundation of Chinese Art at 53 Gordon Square in Bloomsbury, Courtauld's Asian Art resources, comprising 3,750 books (including the Eumorfopoulos Collection) and 7,000 lantern slides and 15,000 photographs, were transferred to SOAS Library ${ }^{11}$ in 1957 . SOAS Library, which up to this time had arranged its collections based on seven geographical regions, established the Art \& Archaeology section. David's collection of ceramics now reside in the British Museum, but his rare book collection and his library, which were previously held by the Foundation, are now held by SOAS Library.

With such donations, Asian Art studies developed rapidly with the Centre of Art \& Archaeology being established as a unit in 1980 before becoming an independent department in 1990. The department is widely acknowledged as having an excellent teaching and research reputation, attracting internationally renowned academics. There are approximately over 55,000 books and several hundred periodicals in the Art \& Archaeology Collection which support their activities.

The Art \& Archaeology Collection is catalogued under an in-house classification system. Classmark F is dedicated for the Art \& Archaeology main collection. The collection is also arranged by its sizes: normal, large, extra large and elephant size books. There are small numbers of 'Reference Only' materials (prefixed 'Ref'), consisting of dictionaries, encyclopaedia and bibliographies. Rare books and manuscripts are kept in the Archives and Special Collections which can be consulted under supervision.

\section{Chinese art and archaeology}

Chinese art has the classmark FF. This classmark is sub-divided according to subject: FFA is for Archaeology, FFB for Inscriptions \& Epigraphy, FFC for Architecture \& Gardens, FFD for Buddhist Art, FFE for Sculpture, FFH for Painting \& Calligraphy etc. Chinese art books written in Chinese text have 
classmarks prefixed with the lower-case 'c'. Roughly 13,000 books are found under classmark FF and approximately half of these books are written in Chinese. Chinese art and archaeology is one of the most well used sections within the Art \& Archaeology Collection.

In terms of print journals, there are around 2,000 Chinese periodical and newspaper titles available at SOAS Library. Over 100 journals can be found under classmark Per 105 and c Per 105, which are dedicated to Chinese art. Among the holdings, about 60 periodicals and magazines published in pre-1949 China are rare or unobtainable outside of China. One example is Dian shi zhai bua bao (點石齋畫報, Dianshizhai pictorial), published between 1884 and 1898 in Shanghai, three times a month. It is a valuable source of Chinese visual culture of the late 19th and early 20th centuries, combining text and outstanding illustrations of traditional Chinese-style paintings and copies of sketches from foreign magazines. ${ }^{12}$ The Library holds original editions from between 1884 and 1895 with bindings that retain the original covers and pull out pictures. Another unique example is $F u$ nï za zhi (婦女雜誌, the Ladies' Journal) published between 1915 and 1931 in Shanghai. The Library has a complete run of this journal which is an important record of the dramatic social, political, economic and cultural changes of women in pre-revolutionary China. Guo cui xue bao (國粹學報 Journal of National Essence) published between 1905 and 1911 highlights scholarly works on sinology, but also includes portraits of celebrities and various drawings such as inscriptions, as well as rubbings and paintings.

SOAS Library subscribes to a number of databases through the UK libraries consortium and individual subscriptions. A large number of Chinese electronic journals are available via Chinese language databases such as CAJ (Chinese Academic Journals, 中国期刊全 文数据库), China Maxx (中文集献) and Duxiu (读秀). Furthermore, digitised collections are accessible, such as Gujin tushi jicheng (古今圖書集成, the Imperial Encyclopaedia), first published in 1726, which chronicles Chinese art, literature, culture and science and Siku Quanshu (四庫全書, Complete Library of the Four Treasuries), published in 1781, which covers Chinese classics, history, literature and philosophy. Both collections are essential resources for Chinese humanity studies.

\section{Notable collections}

SOAS Library has a number of notable collections. The Chinese art collections are especially diverse, ranging from rare books to paintings and from woodblock prints to historically significant objects. One of the world's largest known encyclopaedia is the Yongle Dadian (永樂大典) compiled between 1403 and 1408, commissioned by Yongle emperor in Ming dynasty. Of its 11,095 volumes, fewer than 400 volumes of the three manuscript copies of the set have survived into modern times. ${ }^{13}$ The SOAS Library has 6 of the 51 volumes that can be found in the U.K. ${ }^{14}$

Auction sales catalogues of Asian art provide an important record. The earliest catalogue in the Library's collection is Christie's fine Oriental old porcelain auction held in February 1877. The Library has continued to subscribe to Sotheby's (from 1877 onwards) and Christie's (1879-1959 and from 1974 onwards). Modern \& Contemporary Chinese Art has been added to the current subscription list. 1990 onwards catalogues are located in open shelves in the Library, while pre-1990s catalogues have been moved to closed access areas and are available on request.

The Morrison Collection is one of the main collections in the early history of the School. Robert Morrison (1782-1834) was the first Protestant missionary to China. During his residence in Guangzhou and Macao from 1807-1823, he meticulously collected Chinese books, returning to the UK with around 10,000 volumes. In spite of Morrison's wish to donate his collection to University of Oxford or Cambridge to promote study of Chinese in England, the collection was kept in the London Missionary Society for over 10 years until transferred to the newly founded University College of London in 1836, and finally to SOS in 1922 . The Morrison collection is regarded significant not only because of its size but also its uniqueness. The collection consists of mainly Qing dynasty books, as Morrison's intention had been to collect any available and affordable books on Chinese language, literature, history, religion and culture to introduce Chinese studies to England. As these commercial books were, at the time, not very collectable (Chinese collectors at the time tended to concentrate on collecting rare books of the Ming dynasty and earlier), most of them did not survive. These days Qing Dynasty books are often rarer than those from the Ming dynasty. ${ }^{15}$ The collection covers broad subjects including books on coins, jades, calligraphy, military art and agriculture in art.

A gift from Sir Reginald Johnston (1874-1938), who is probably best known to the world as the personal tutor of Puyi (溥儀, 1906-1967), the last Emperor of China, is another outstanding and historically significant collection. After Johnston returned to UK, he became one of the first Professors of Chinese at SOS, teaching between 1931 and 1937. Johnston bequeathed his library to the School, including some books given to him by Puyi himself. 
These are particularly important because 'they were printed in the imperial Palace for the use of the imperial family and household, and have never been obtainable in the book-market'. ${ }^{16}$ This collection is particularly rich in books relating to Buddhism, mountain chronicles and the literature of the 1920s, including autographed editions of famous writers such as Xu Zhimo (徐志摩, 1896-1931) and Hu Shi (胡適, 1891-1962). Among this priceless collection, it is worthy to highlight Chen Shu hua hui (陳舒花卉, Chen Shu's flower painting) which is kept in the Archives and Special Collections department of SOAS Library. This beautiful album, consisting of 10 flower paintings, was Emperor Puyi's gift to Johnston. The first picture bears the seal of the Emperor on a peony painting. Inside the album, Puyi's inscription to Johnston is written in Chinese and English. Another remarkable farewell gift is a Chinese fan donated by Elizabeth Sparshott to the Percival David Foundation, which became part of the SOAS collection in 2009. This black fan, with poems from Chinese classical literature, was written by Puyi for Johnston to remember their companionship. depict popular operatic stories. The New Year pictures include common themes such as Door gods, Kitchen gods and the Ox calendar.

\section{Modern and contemporary Chinese}

\section{art}

Art historians define the period of modern Chinese art from 1839 to 1976 (i.e. the Opium Wars, the Republican period and the Maoist years), whereas contemporary Chinese art is generally understood as the reform era after the death of Mao Zedong. ${ }^{19}$ With increasing attention paid to modern and contemporary Chinese art (including photography and new media), SOAS library has made deliberate efforts to build its collection to reflect this emphasis.

Modern and contemporary Chinese art material in SOAS has been collected primarily to serve its teaching and research needs. The Department of History of Art \& Archaeology runs two courses: 'Art \& Culture in Modern China' and 'Art of Modern and

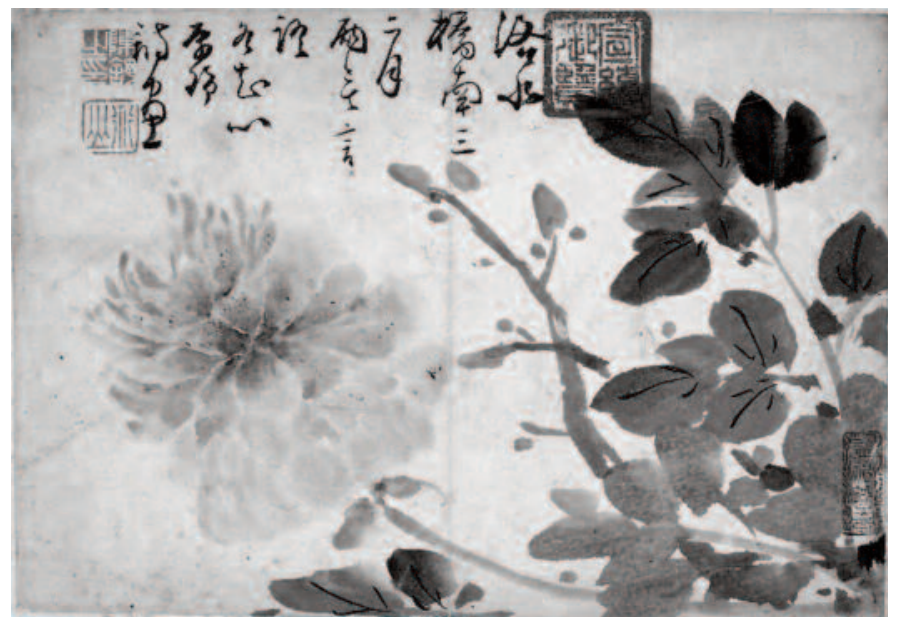

The Library has acquired over a hundred Chinese woodblock popular prints, including New Year pictures (年画 nianhua), produced in Suzhou, and predominantly from the 18th and 19th centuries. These kinds of prints appeared in the Song dynasty and gained popularity during the Ming dynasty before being mass-produced in Qing dynasty. They were displayed on the doors and walls of ordinary people's house for decoration. Not many of them survived as they were not considered collectable items. ${ }^{17}$ The collection is unique in that such an extensive collection cannot be found elsewhere in the UK. ${ }^{18}$ Some of the woodblock prints in the SOAS collection are illustrations of historic events, such as the SinoJapanese war and the Boxer rebellion, while other

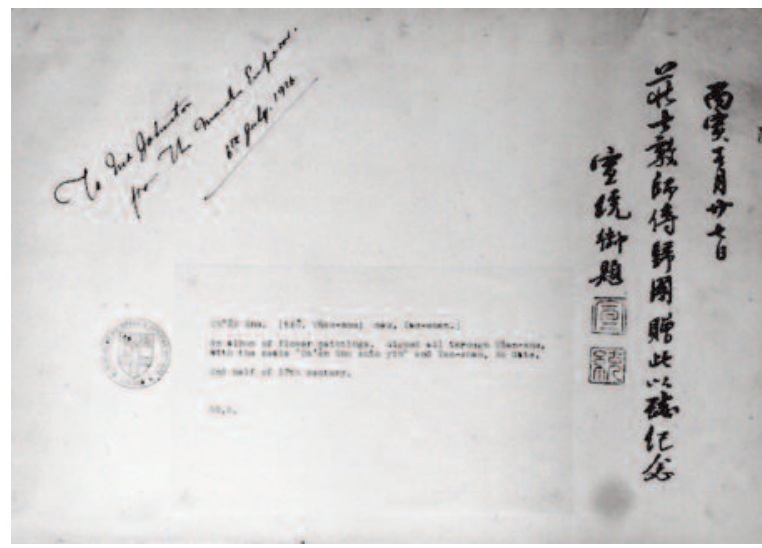

Chen Shu hua hui (陳舒花卉 Chen Shu flower painting) China, 17th century. leaf 1 and verso of front cover. MS/62612.

Contemporary China (since 1800)'. The Library has collected about 180 core texts and source texts to support these courses. The criteria to build the collection of this newly emerging area are still being defined. Guides, such as those produced by Stanford University ${ }^{20}$ alerts from publishers, academic forums ${ }^{21}$ and recommendations by researchers, as well as the collection development policies of institutions where significant research on modern and contemporary Chinese art has been published in recent years, are currently proving to be the most fruitful. However, it is also recognized that in order to build a collection that can anticipate future academic interests, it is necessary to consider the collection development 


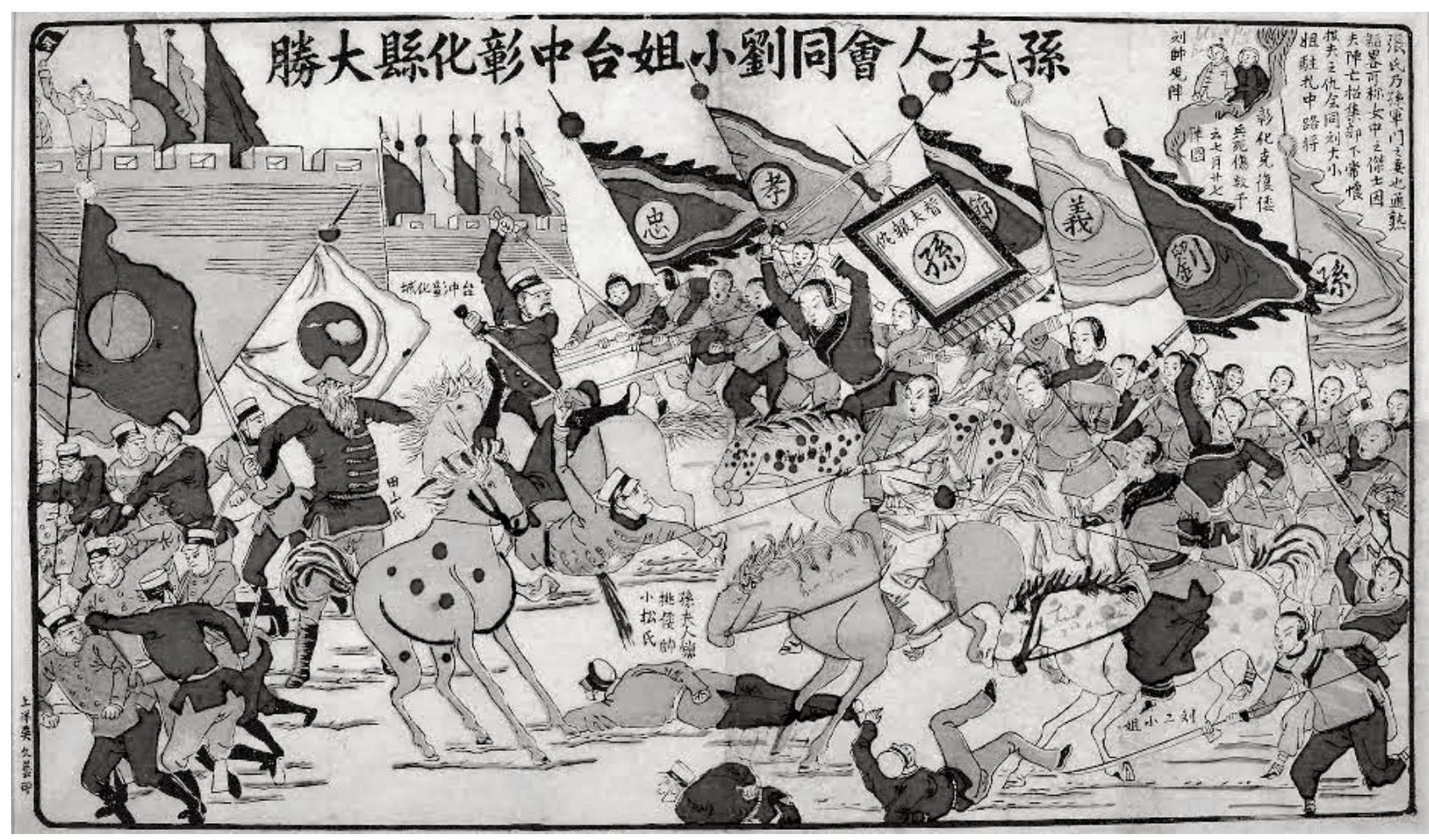

Sun's wife and Miss Liu jointly celebrate the great victory in Changhua in Taiwan (孫夫人會同劉小姐台中彰化縣大滕) by $\mathrm{Wu}$ Wenyi. Shanghai after 1895. Chinese woodblock prints 11.

policies and selection criteria of major academic libraries in China. This is on-going, and so far, SOAS has started subscribing to several journals dedicated to Chinese 20th and 21st century art such as Yishu: Fournal of Contemporary Chinese Art, Yi shu Dang dai (藝術當代, Art China), and New Art (新美術).

Moreover, Sotheby's and Christie's auction catalogues on modern and contemporary Chinese art, as well as exhibition catalogues (e.g. 798 Art Zone in Beijing, Biennials) have been used recently to identify scholarly trends in this quickly changing field.

A recent notable acquisition on Chinese contemporary art resulted from the exhibition Chinascape: Contemporary Chinese Photography which was held at SOAS Library in 2011. Photographs were presented of a number of high-profile independent artists in China, which provided a rare opportunity to glimpse trends in contemporary Chinese visual art. After the exhibition, four pieces of the Postman (邮差) series by Shanghai based artist Maleonne (also known as Ma Liang (马良)) were donated to the SOAS Library collection.

\section{Future developments and projects}

SOAS Library has always sought to collaborate with other relevant libraries. In November 2013, the new Taiwan Resource Centre for Chinese Studies
(TRCCS) was launched at the SOAS Library. This is a collaborative project between Taiwan's National Central Library, the SOAS Library, and the SOAS Centre of Taiwan Studies. The TRCCS holds an initial donation of over 800 books and DVDs on Taiwan's politics, external relations, society \& culture, modern history and film studies. In addition, the TRCCS will offer a range of databases for Taiwan and Chinese studies. Another noteworthy collaboration is with Sun Yat-sen University Library in China which will support the digitisation and preservation of some of the books from Morrison collection as part of its Guangzhou Dadian (广州大典) project.

Furthermore, a project has just been initiated to digitise the Chinese woodblock prints in order to further improve accessibility to this rare collection.

SOAS Library has been fortunate enough to enrich its collection through gifts and donations. In the earlier years, the Library actively sought materials to build its collections. If the quantity was the issue then, quality matters more nowadays. Due to budget and space constraints, collections are shaped under the Collection Development Policy ${ }^{22}$ in close liaison with SOAS academics. Fortunately, the School's centenary strategy for $2016^{23}$ has identified China as a growth priority as evidenced by the establishment of the China Institute, a new academic centre in SOAS. As mentioned earlier, emphasis is also being placed on modern and contemporary Chinese art, anticipating 
that the expanding collection will act as a catalyst to attract more researchers to this area.

As it has throughout SOAS's history, the Library and the Chinese Art \& Archaeology Collection continue to evolve to reflect new research interests, academic courses and the needs of its users.

\section{References}

1. Keith Webster and Rosemary Seton, 'The SOAS Library and archives,' in: SOAS since the Sixties, eds. David Arnold and Christopher Shackle (London: School of Oriental and African Studies, 2003), 130.

2. Lawrence Roger Lumley Scarborough, Report of the Interdepartmental Commission of Enquiry on Oriental, Slavonic, East European and African Studies (London: H.M.S.O, 1947).

3. Webster and Seton, SOAS since the Sixties, 130.

4. Hayter Report (Sir William Hayter), Report of the Sub-Committee on Oriental, Slavonic, East European and African Studies (London: University Grants Committee,1961).

5. Barbara Spina, 'SOAS Library: why it is special', http://www.soas.ac.uk/library/about/what-makessoas-library-special/ii-soas-library.html

6. Ibid.

7. Vision, Mission and Aims of the Library, http://www.soas.ac.uk/library/about/

8. C.H. Phillips, The School of Oriental \& African Studies, University of London, 1917-1967, (London: University School of Oriental and African Studies, 1967), 45.

9. Yoshiko Yasumura, 'George Eumorfopoulos and the University of London.,' Orientation 38, no.8 (2007): 86-90.

10. Stacey Pierson. 'An Academic Collector: Sir Percival David and the School of Oriental and African Studies,' Orientation 38, no.8 (2007): 9193.

11. Subject statements: History of Art \& Archaeology, http://www.soas.ac.uk/library/ about/what-makes-soas-library-special/iv-subjectcollections.html\#Art
12. Christopher A Reed. 'Re/Collecting the Sources: Shanghai's Dianshizhai Pictorial and Its Place in Historical Memories, 1884-1949,' Modern Chinese Literature and Culture 12, no.2 (2000): 44-71.

13. 'Rare treasures of an ancient past', Chinadaily.com.cn, September 9, 2009.

14. 'Expert to urge to share', Xinhua News Agency, April 17, 2002.

15. Andrew West, Catalogue of the Morrison Collection (London: School of Oriental and African Studies, 1998), xvi.

16. Shona Airlie, Scottish Mandarin: The Life and Times of Sir Reginald Fobnston (Hong Kong: Hong Kong University Press, 2012), 235.

17. Yin Hwang (Lecturer in Hong Kong University) in discussion with the author, November 2013.

18. John T. Carpenter and Yoshiko Yasumura 'East Asia' in: Objects of Instruction, ed. Anna Contadini (London: the School of Oriental and African Studies, 2007), 27.

19. Chinese Art: Modern and Contemporary, http://library.stanford.edu/guides/chinese-artmodern-and-contemporary

20. Arts of China Consortium, http://www.nyu.edu/gsas/dept/fineart/html/chine se/links.html

21. MCLC Resource Centre, http://mclc.osu.edu/rc/ART.htm

22. Library Collection Development Policy, http://www.soas.ac.uk/library/about/collectiondev policy/

23. SOAS 2020 - Vision and Strategy for the 2016 Centennial and beyond, http://www.soas.ac.uk/directorate/visionandstrate gy/file23384.pdf

Jiyeon Wood

Subject Librarian for Arts \& Multi-Media

SOAS, University of London

Thornhaugh Street, Russell Square

London WC1H OXG

$U K$

Email:jw50@soas.ac.uk 